\title{
Selective Removal of Hemoglobin from Blood Using Hierarchical Copper Shells Anchored to Magnetic Nanoparticles
}

\author{
Youxun Liu,, ${ }^{1,2}$ Yaokun Wang, ${ }^{1}$ Mingyang Yan, ${ }^{1}$ and Juan Huang ${ }^{1}$ \\ ${ }^{1}$ School of Basic Medical Sciences, Xinxiang Medical University, Jinsui Avenue 601, Xinxiang, Henan 453003, China \\ ${ }^{2}$ Henan Collaborative Innovation Center of Molecular Diagnostics and Laboratory Medicine, Jinsui Avenue 601, Xinxiang, \\ Henan 453003, China \\ Correspondence should be addressed to Juan Huang; huangjuan@xxmu.edu.cn
}

Received 21 November 2016; Accepted 29 January 2017; Published 21 February 2017

Academic Editor: Kevin M. Coombs

Copyright (C) 2017 Youxun Liu et al. This is an open access article distributed under the Creative Commons Attribution License, which permits unrestricted use, distribution, and reproduction in any medium, provided the original work is properly cited.

\begin{abstract}
Hierarchical copper shells anchored on magnetic nanoparticles were designed and fabricated to selectively deplete hemoglobin from human blood by immobilized metal affinity chromatography. Briefly, $\mathrm{CoFe}_{2} \mathrm{O}_{4}$ nanoparticles coated with polyacrylic acid were first synthesized by a one-pot solvothermal method. Hierarchical copper shells were then deposited by immobilizing $\mathrm{Cu}^{2+}$ on nanoparticles and subsequently by reducing between the solid $\mathrm{CoFe}_{2} \mathrm{O}_{4} @ \mathrm{COOH}$ and copper solution with $\mathrm{NaBH}_{4}$. The resulting nanoparticles were characterized by scanning electron microscopy, transmission electron microscopy, Fourier transform infrared spectrometry, X-ray photoelectron spectroscopy, and vibrating sample magnetometry. The particles were also tested against purified bovine hemoglobin over a range of $\mathrm{pH}$, contact time, and initial protein concentration. Hemoglobin adsorption followed pseudosecond-order kinetics and reached equilibrium in $90 \mathrm{~min}$. Isothermal data also fit the Langmuir model well, with calculated maximum adsorption capacity $666 \mathrm{mg} \mathrm{g}^{-1}$. Due to the high density of $\mathrm{Cu}^{2+}$ on the shell, the nanoparticles efficiently and selectively deplete hemoglobin from human blood. Taken together, the results demonstrate that the particles with hierarchical copper shells effectively remove abundant, histidine-rich proteins, such as hemoglobin from human blood, and thereby minimize interference in diagnostic and other assays.
\end{abstract}

\section{Introduction}

In clinical diagnosis and medical research, changes in blood indices are critical parameters that reflect physiological status or indicate pathology [1]. However, some biomarkers in the blood, including DNA, RNA, and many proteins, are generally present at very low concentrations $[2,3]$ and are difficult to detect due to severe interference from highly abundant proteins such as hemoglobin $[4,5]$. Consequently, depletion of such abundant proteins is an essential prerequisite.

Among the many depletion methods currently available, affinity-based techniques are some of the most effective and have become routine [6-8]. For example, immobilized metal affinity chromatography is now frequently used to separate histidine-rich proteins based on the selective interaction between immobilized metal ions and electron donor groups in proteins containing several consecutive histidine residues [9]. Separation is typically achieved via transition metal ions like $\mathrm{Cu}^{2+}, \mathrm{Ni}^{2+}, \mathrm{Zn}^{2+}$, or $\mathrm{Co}^{2+}$, which are typically chelated into molecules covalently bound to matrices such as dextrin gels, polystyrene beads, or nanoparticles. Of these, magnetic nanoparticles (MNPs) have been widely used because of biocompatibility, biodegradability, stability, facile surface functionalization, and magnetic features that facilitate convenient separation. Indeed, these nanoparticles have been used not only in protein purification, but also in drug delivery, diagnostic imaging, pollution removal, and enzyme immobilization [10-13]. For instance, metals immobilized on a magnetic matrix are widely used to effectively deplete abundant proteins and peptides from proteomic samples [14]. Unfortunately, the most commonly used MNPs are based on iron oxides and are thus susceptible to leaching in acidic conditions. Consequently, inorganic $\mathrm{SiO}_{2}$ has been used as a shell to protect magnetic cores $[15,16]$, although such a shell may also significantly reduce magnetism. Thus, it is necessary to fabricate new multifunctional composites that 
are both strongly magnetic and chemically stable. $\mathrm{CoFe}_{2} \mathrm{O}_{4}$, a thermally and chemically stable ferrite, appears to be one such composite $[17,18]$.

$\mathrm{Cu}^{2+}$ and $\mathrm{Ni}^{2+}$ are the most frequently used metal ions to magnetically separate proteins by affinity chromatography. For example, Chen et al. $[19,20]$ fabricated MNPs coated with iminodiacetic acid and charged with $\mathrm{Cu}^{2+}$ or $\mathrm{Ni}^{2+}$ to selectively adsorb histidine-rich bovine hemoglobin ( $\mathrm{BHb})$. $\mathrm{BHb}$ was also selectively captured on $\mathrm{Cu}^{2+}$-EDTA- $\mathrm{Fe}_{3} \mathrm{O}_{4}$ magnetic particles synthesized by Ding et al. through a onepot solvothermal method [21]. However, a major disadvantage of the above systems is the low metal ion density on the surface, which leads to a low adsorption capacity for protein and restricts their practical application in protein separation. Consequently, well-designed magnetic nanomaterials with higher metal density have emerged as powerful candidates for meeting the above-mentioned requirement. Recently, Liu and coworkers [22] achieved highly selective isolation of polyhistidine-tagged proteins from cell lysates using a graphene-nickel composite. Intriguingly, Lee et al. [23] demonstrated that $\mathrm{Ni}$ nanoparticles are coated with $\mathrm{NiO}$ capture and magnetically separate histidine-tagged proteins. A hierarchical nickel shell anchored on silica coated magnetic $\mathrm{Fe}_{3} \mathrm{O}_{4} @ \mathrm{SiO}_{2}$ nanoparticles has been designed and constructed, and the high $\mathrm{Ni}^{2+}$ density is found on the shell, which results in a high adsorption capacity for $\mathrm{BHb}$ [24]. The above literature shows that a hierarchical nickel shell can provide higher metal ion density on the surface of MNPs, which help to improve the protein adsorption capacity. However, there are few reports that $\mathrm{Cu}$-coated core-shell magnetite nanoparticles are used for selective capture of histidine-rich proteins. This inspired us to evaluate whether magnetite nanoparticles coated with copper could be applied to selectively capture histidine-rich $\mathrm{BHb}$ or human hemoglobin. We note that $\mathrm{Cu}$-coated core-shell $\mathrm{CoFe}_{2} \mathrm{O}_{4}$ composite microspheres are easily and magnetically separated from aqueous solutions and have improved chemical stability due to addition of $\mathrm{Co}^{2+}$. Further, $\mathrm{Cu}$ shell/core architecture may also protect a magnetic core without compromising purification efficiency. More importantly, a hierarchical copper shell may provide a high $\mathrm{Cu}^{2+}$ density on the surface of MNPs, which can increase adsorption capacity for protein.

Here, we describe a simple method to synthesize carboxyl-functionalized, $\mathrm{Cu}$-coated, magnetic $\mathrm{CoFe}_{2} \mathrm{O}_{4}$ composite microspheres that rapidly and efficiently capture proteins like hemoglobin. In this method, $\mathrm{CoFe}_{2} \mathrm{O}_{4}$ particles functionalized with polyacrylic acid are first synthesized via a onepot solvothermal route and then coated with copper ions. The copper ions are then reduced to $\mathrm{Cu}$ metal by aqueous $\mathrm{NaBH}_{4}$, resulting in anchored, hierarchical Cu shells. The particles were then characterized without further processing by scanning electron microscopy (SEM), transmission electron microscopy (TEM), Fourier transform infrared spectrometry (FT-IR), energy dispersive X-ray spectroscopy (EDX), and vibrating sample magnetometry (VSM). The particles were then tested against bovine hemoglobin to assess kinetic and isothermal adsorption. Finally, the particles were tested against human blood.

\section{Materials and Methods}

2.1. Reagents and Materials. All chemicals, including ferric chloride hexahydrate $\left(\mathrm{FeCl}_{3} \cdot 6 \mathrm{H}_{2} \mathrm{O}\right)$, cobalt chloride $\left(\mathrm{CoCl}_{2}\right)$, copper (II) sulfate pentahydrate $\left(\mathrm{CuSO}_{4} \cdot 5 \mathrm{H}_{2} \mathrm{O}\right)$, polyacrylic acid, and sodium borohydride $\left(\mathrm{NaBH}_{4}\right)$ were analytical grade (Sinopharm Chemical Reagent Company) and were used as received without further purification. Deionized water was used throughout. Protein molecular weight markers, bovine hemoglobin (BHb, molecular weight $64.5 \mathrm{kDa}, \mathrm{pI} 6.8$ ), and bovine serum albumin (BSA, molecular weight $67 \mathrm{kDa}$, pI 4.7) were purchased from Dingguo Biological Technology Company (Beijing, China). Human blood was obtained from a healthy volunteer and immediately used.

2.2. Synthesis of Cu Magnetic Particles. Cu magnetic particles (Cu-MNPs) were synthesized in two continuous steps. First, magnetic particles functionalized with polyacrylic acid were synthesized via a simple solvothermal route as previously described [24], with some modification. Briefly, $\mathrm{FeCl}_{3} \cdot 6 \mathrm{H}_{2} \mathrm{O}$ $(0.5 \mathrm{~g})$ and $\mathrm{CoCl}_{2}(0.23 \mathrm{~g})$ were dissolved into a clear solution in $50 \mathrm{~mL}$ water and mixed with $15 \mathrm{~mL}$ polyacrylic acid (PAA) and $15 \mathrm{~mL} 80 \%$ hydrated hydrazine. The mixture was vigorously stirred until homogeneous, transferred to a $250 \mathrm{~mL}$ Teflon-lined stainless-steel autoclave, and reacted at $180^{\circ} \mathrm{C}$ for $10 \mathrm{~h}$. The final product was collected with a magnet, washed with ethanol and deionized water several times in this order, and dried overnight at $50^{\circ} \mathrm{C}$ in a vacuum oven. The PAA@MNPs were obtained. Subsequently, $0.5 \mathrm{~g}$ of the product was mixed with $50 \mathrm{~mL} 0.2 \mathrm{mM} \mathrm{CuSO}_{4}$ and then with $10 \mathrm{~mL}$ water containing $0.4 \mathrm{~g} \mathrm{NaBH}_{4}$. The mixture was mechanically stirred at room temperature overnight, and the resulting nanoparticles were isolated by magnetic decantation, washed with ethanol and deionized water several times in this order, and dried overnight at $50^{\circ} \mathrm{C}$ in a vacuum oven. Following the steps above, Co ${ }^{2+} @ P A A @ M N P s$, $\mathrm{Ni}^{2+} @ \mathrm{PAA} @ \mathrm{MNPs}$, and $\mathrm{Cu}^{2+} @ \mathrm{PAA} @ M N P s$ were synthesized without adding $\mathrm{NaBH} 4$.

2.3. Characterization. Nanoparticles were characterized on an FT-IR spectrometer (Thermo Nicolet Corporation, Waltham, MA, USA), a Zetasizer Nano 100 (Malvern, Worcestershire, UK), and a high-resolution transmission electron microscope (HRTEM; JEOL-2010, Japan). SEM and EDX micrographs were obtained with a field emission scanning electron microscope (ZEISS Ultra 55, Carl Zeiss, Germany), while X-ray photoelectron spectra were recorded on an electron spectrometer emitting a $300 \mathrm{~W}$ Al KR radiation (ESCALAB220i-XL, VG Scientific, UK). Magnetization was measured at room temperature on a vibrating sample magnetometer (PPMS-9, Quantum Design, San Diego, USA).

2.4. Adsorption of BHb. Due to its similarity to human hemoglobin, $\mathrm{BHb}$ was used as a model histidine-rich protein. Adsorption to $\mathrm{Cu}-\mathrm{MNPs}$ was assessed over a range of $\mathrm{pH}$, contact time, and initial protein concentration. The adsorption kinetic and adsorption isotherm were measured 


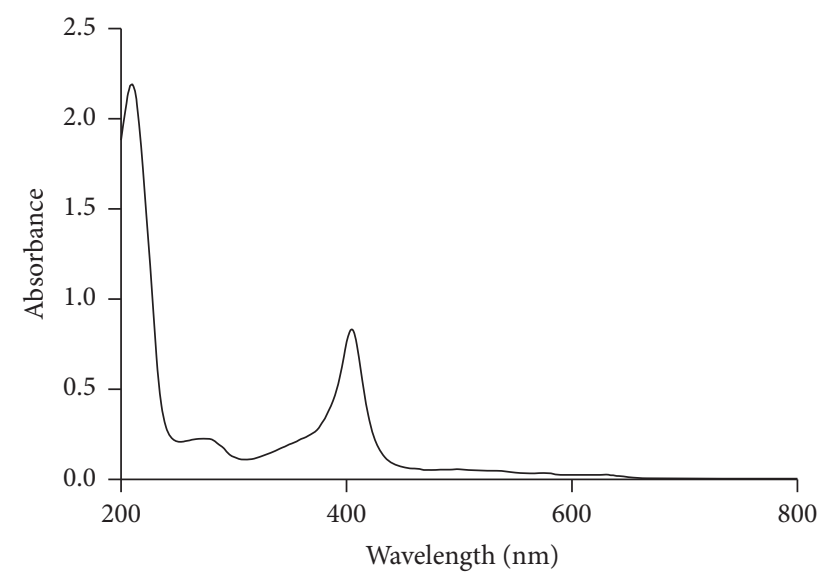

FIgURE 1: UV-visible spectrum of $\mathrm{BHb}$.

in batch experiments. In a typical adsorption experiment, $0.02 \mathrm{~g} \mathrm{Cu}-\mathrm{MNPs}$ was shaken for $90 \mathrm{~min}$ at room temperature with $20 \mathrm{~mL} 1 \mathrm{mg} / \mathrm{mL}$ BHb in Tris- $\mathrm{HCl}$ pH 8.5. After magnetic decantation, the absorbance of the supernatant at $408 \mathrm{~nm}$ was measured using a UV-1700 spectrophotometer (Shimadzu, Kyoto, Japan). We note that $\mathrm{BHb}$ has maximum absorbance at $408 \mathrm{~nm}$ (Figure 1).

Adsorption was calculated according to

$$
Q=\frac{\left(C_{0}-C_{1}\right) V}{M},
$$

where $Q\left(\mathrm{mgg}^{-1}\right)$ is the amount of $\mathrm{BHb}$ adsorbed, $C_{0}$ $\left(\mathrm{mg} \mathrm{mL}^{-1}\right)$, and $C_{1}\left(\mathrm{mg} \mathrm{mL}^{-1}\right)$ are the initial and residual concentration of $\mathrm{BHb}$ in the supernatant, respectively, $V$ $(\mathrm{mL})$ is the reaction volume, and $M(\mathrm{~g})$ is the mass of $\mathrm{Cu}-$ MNPs. The effect of $\mathrm{pH}$ on adsorption was tested from 4.0 to 7.0 in $0.1 \mathrm{M}$ citric acid sodium hydrogen phosphate buffer, and from 7.5 to 9.5 in $0.1 \mathrm{M}$ Tris- $\mathrm{HCl}$ buffer. The effect of contact time was assessed while keeping the initial concentration of $\mathrm{BHb}$ constant at $1.0 \mathrm{mg} \mathrm{mL}^{-1}$. Adsorption kinetic data were fitted to pseudo-first-order or pseudo-second-order models $[25,26]$, which can be expressed as

$$
\begin{aligned}
\ln \left(Q_{e}-Q_{t}\right) & =\ln Q_{e}-k_{1} t \\
\frac{t}{Q_{t}} & =\frac{1}{K_{2} Q_{e}^{2}}+\frac{t}{Q_{e}},
\end{aligned}
$$

where $Q_{t}\left(\mathrm{mg} \mathrm{g}^{-1}\right)$ is the adsorbed BHb at time $t$ and and $Q_{e}$ $\left(\mathrm{mg} \mathrm{g}^{-1}\right)$ is the adsorbed BHb at equilibrium. $k_{1}\left(\mathrm{~min}^{-1}\right)$ and $k_{2}\left(\mathrm{~g} \mathrm{mg}^{-1} \mathrm{~min}^{-1}\right)$ are the pseudo-first-order rate constant and pseudo-second-order rate constant, respectively.

The effect of initial protein concentration was investigated from 0.1 to $3.0 \mathrm{mg} \mathrm{mL}^{-1}$, and the adsorption isothermal data were fitted to the Freundlich model or the Langmuir [27, 28], which can be expressed as

$$
\begin{aligned}
\frac{C_{e}}{Q_{e}} & =\frac{C_{e}}{Q_{m}}+\frac{1}{K_{L} Q_{m}} \\
\ln Q_{e} & =\ln K_{F}+\frac{1}{n} \ln C_{e},
\end{aligned}
$$

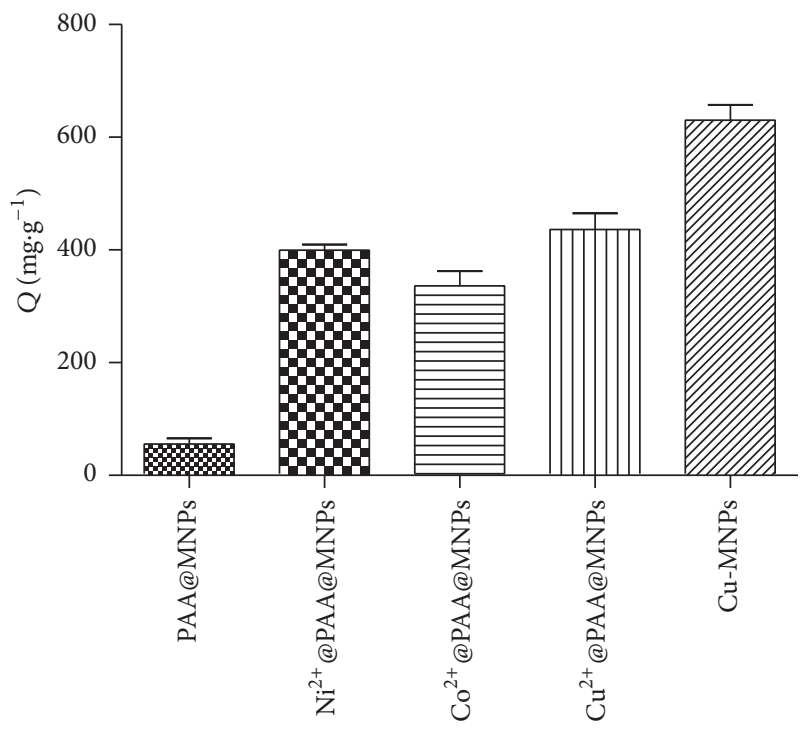

FIGURE 2: Adsorption capacity of the nanoparticles with different metal ions on the surface.

where $Q_{e}\left(\mathrm{mg} \mathrm{g}^{-1}\right)$ is the adsorbed $\mathrm{BHb}$ at equilibrium and $Q_{m}\left(\mathrm{mgg}^{-1}\right)$ is the maximum $\mathrm{BHb}$ that can be adsorbed. $C_{e}\left(\mathrm{mg} \mathrm{mL}^{-1}\right)$ denotes the residual concentration of $\mathrm{BHb}$ in solution at equilibrium, while $K_{F}\left(\mathrm{mg} \mathrm{g}^{-1}\right)$ is the Freundlich constant reflecting the maximum adsorption capacity. $1 / n$ is the adsorption intensity and $K_{L}\left(\mathrm{~mL} \mathrm{mg}^{-1}\right)$ is the Langmuir constant, which is related to the energy of adsorption.

2.5. Selectivity. Due to similarities in abundance, molecular weight, and volume [29], BSA was used as a model competing protein to evaluate the selectivity of $\mathrm{Cu}-\mathrm{MNPs}$ for BHb. Selectivity was tested using $20 \mathrm{~mL}$ solutions containing either protein at $1 \mathrm{mg} \mathrm{mL}^{-1}$ or a mix of both proteins at $1 \mathrm{mg} \mathrm{mL}^{-1}$ each. Supernatants were analyzed on a UV1700 spectrophotometer (Shimadzu, Kyoto, Japan), as BHb and serum albumin have characteristic absorbance peaks at $406 \mathrm{~nm}$ and $280 \mathrm{~nm}$, respectively.

2.6. Depletion of Hemoglobin from Human Blood. To evaluate potential use in the clinic, Cu-MNPs $(0.02 \mathrm{~g}$ ) were used to deplete hemoglobin from a sample of human blood, which was diluted 100 -fold in $0.1 \mathrm{M}$ Tris- $\mathrm{HCl} \mathrm{pH}$ 8.5. After magnetic separation, depleted and control samples were analyzed by spectrophotometry and sodium dodecyl sulfatepolyacrylamide gel electrophoresis (SDS-PAGE).

\section{Results and Discussion}

3.1. Adsorption Capacity of the Nanoparticles with Different Metal Ions on the Surface. As shown in Figure 2, the adsorption capacities of the PAA@MNPs, Co ${ }^{2+} @ P A A @ M N P s$, $\mathrm{Ni}^{2+} @ P A A @ M N P s$, and $\mathrm{Cu}^{2+} @ P A A @ M N P s w e r e$ compared. The result showed that the adsorption capacity of MNPs with $\mathrm{Cu}^{2+}$ on the surface was highest among these nanoparticles, so $\mathrm{Cu}^{2+}$ was chosen for $\mathrm{BHb}$ adsorption and magnetic 


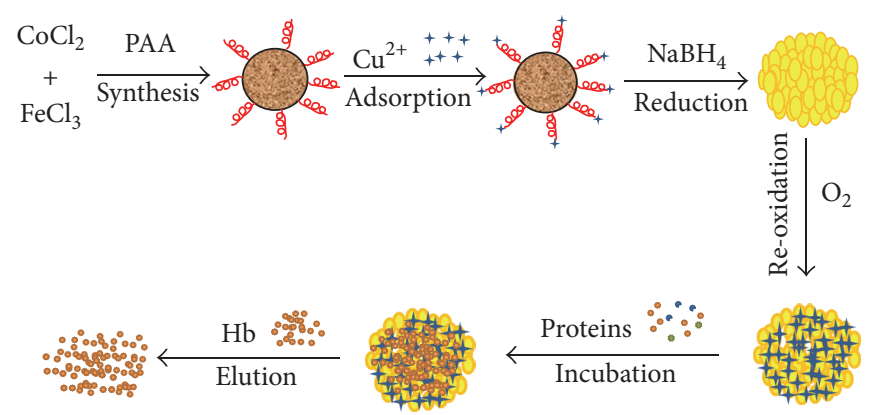

Scheme 1: Schematic illustration of the strategy for preparation of $\mathrm{Cu}-\mathrm{MNPs}$ and $\mathrm{Hb}$ adsorption.

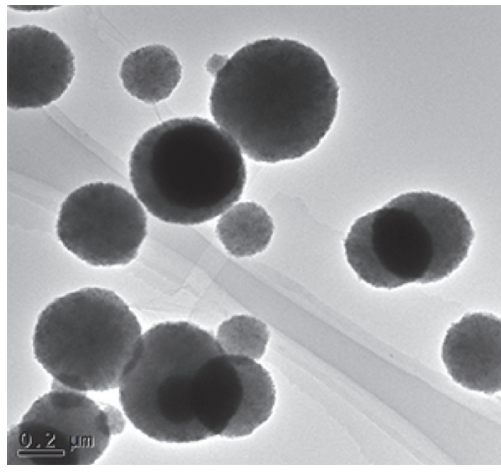

(a)

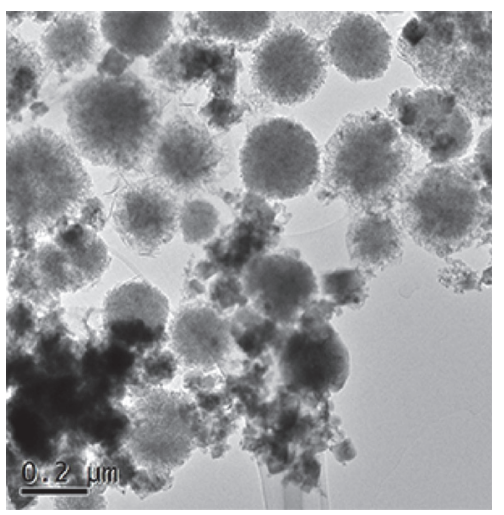

(d)

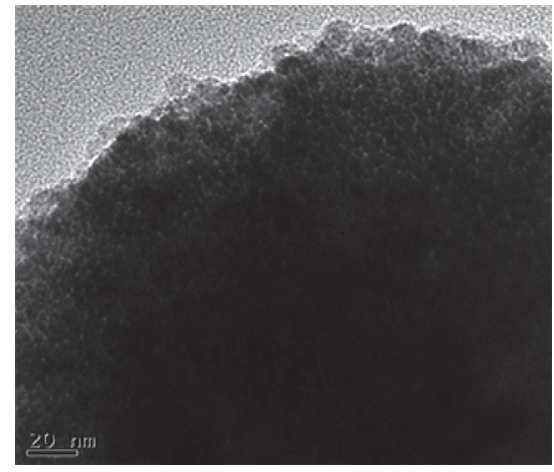

(b)

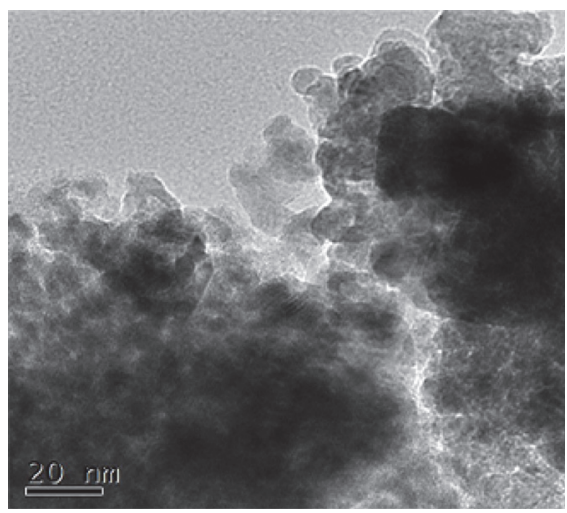

(e)

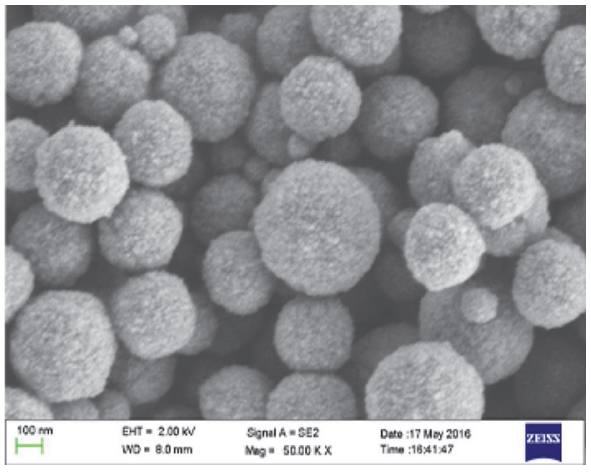

(c)

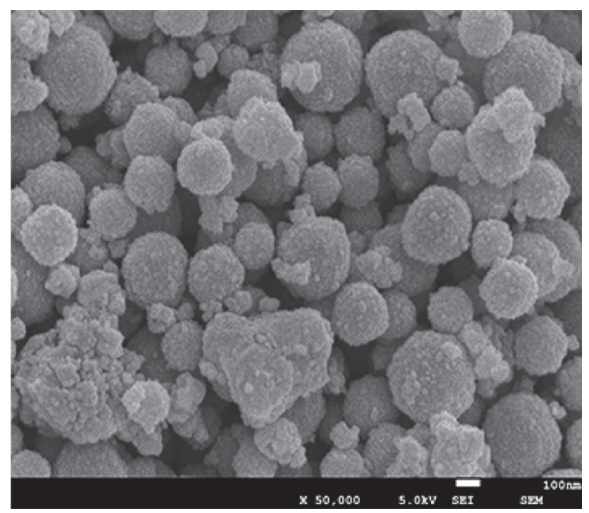

(f)

FIGURE 3: TEM images of magnetic nanoparticles (P-MNPs) before ( $a, b)$ and after loading with copper (Cu-MNPs) (d, e). SEM images of magnetic nanoparticles (P-MNPs) before (c) and after loading with copper (Cu-MNPs) (f).

particles with copper shell had been explored further for $\mathrm{BHb}$ adsorption. In fact, the adsorption capacity of MNPs after coating copper shell was higher than that of $\mathrm{Cu}^{2+}$ @PAA@MNPs.

3.2. Synthesis and Characterization of $\mathrm{Cu}$-MNPs. The preparation of $\mathrm{Cu}-\mathrm{MNPs}$ is illustrated in Scheme 1, along with the proposed mechanism by which it separates target proteins by metal affinity. Surface morphology and architecture are shown in TEM and SEM images in Figure 3, which reveal that magnetic nanoparticles functionalized with polyacrylic acid (P-MNPs) are spherical before (Figure 3(a)) and after loading with $\mathrm{Cu}$ (Figure 3(d)). Based on TEM images, the nanoparticles gained an obvious flower-like core with a clear shell upon loading with copper (Figure $3(\mathrm{~d})$ ). In comparison to P-MNPs (Figures 3(b) and 3(c)), the surface became rougher and very fine particles appeared (Figures 3(e) and $3(\mathrm{f})$ ) after immobilized $\mathrm{Cu}^{2+}$ was reduced to $\mathrm{Cu}$ metal by $\mathrm{NaBH}_{4}$, perhaps due to the formation of $\mathrm{Cu}$ core/shell composite microspheres. The TEM images showed that PMNPs were well-dispersed, but $\mathrm{Cu}-\mathrm{MNPs}$ had slight aggregation in water. Furthermore, these TEM and SEM images indicated that the sizes of P-MNPs and Cu-MNPs were not uniform. 


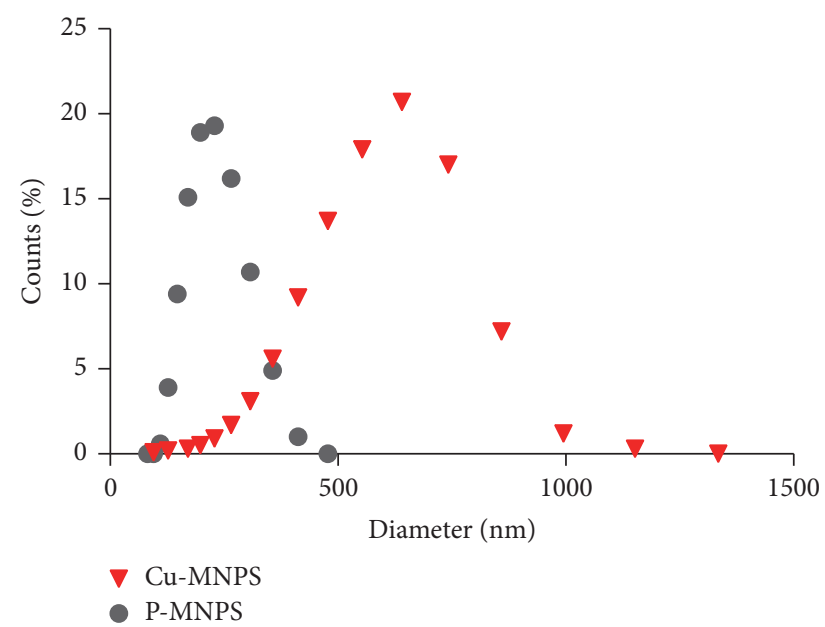

FIgURE 4: Particle size distribution of magnetic nanoparticles with or without copper.

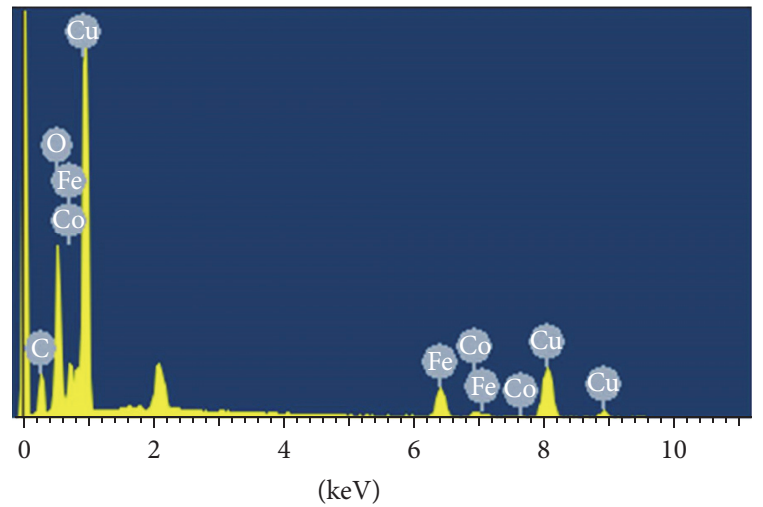

Figure 5: Energy dispersive X-ray spectrum of Cu-MNPs.

Figure 4 shows the particle size distribution of magnetic nanoparticles with or without copper. The latter had an average hydrodynamic size of about $281 \mathrm{~nm}$, the hydrodynamic diameter increased to $513 \mathrm{~nm}$ after loading, indicating that a very thick $\mathrm{Cu}$ shell may have been deposited.

Copper is easily identified in the energy dispersive X-ray spectra of selected surfaces in Cu-MNPs (Figure 5). Remarkably, the particles are more than $40 \%$ Cu by weight (Table 1 ), implying that a large amount of the metal was immobilized, and corroborating the previous result that copper-loaded nanoparticles are larger than unloaded particles.

Vibrating sample magnetometry at room temperature indicated that the saturation magnetization value was $60 \mathrm{emu} \mathrm{g}^{-1}$ and $48.0 \mathrm{emu} \mathrm{g}^{-1}$ for unloaded and copper-loaded magnetic nanoparticles, respectively (Figure 6). Although magnetization slightly decreased after copper loading, the remaining magnetic strength was sufficient to allow easy separation of copper-loaded particles from aqueous solutions in less than $30 \mathrm{~s}$ by applying an external magnetic field.

The survey and the respective element XPS of $\mathrm{Cu}-$ MNPs are given in Figure 7. The binding energies of $\mathrm{O}$ (1s, $529.88 \mathrm{eV}), \mathrm{C}(1 \mathrm{~s}, 284.07 \mathrm{eV}), \mathrm{Fe}(2 \mathrm{p}, 710.3 \mathrm{eV})$, Co $(2 \mathrm{p}$,

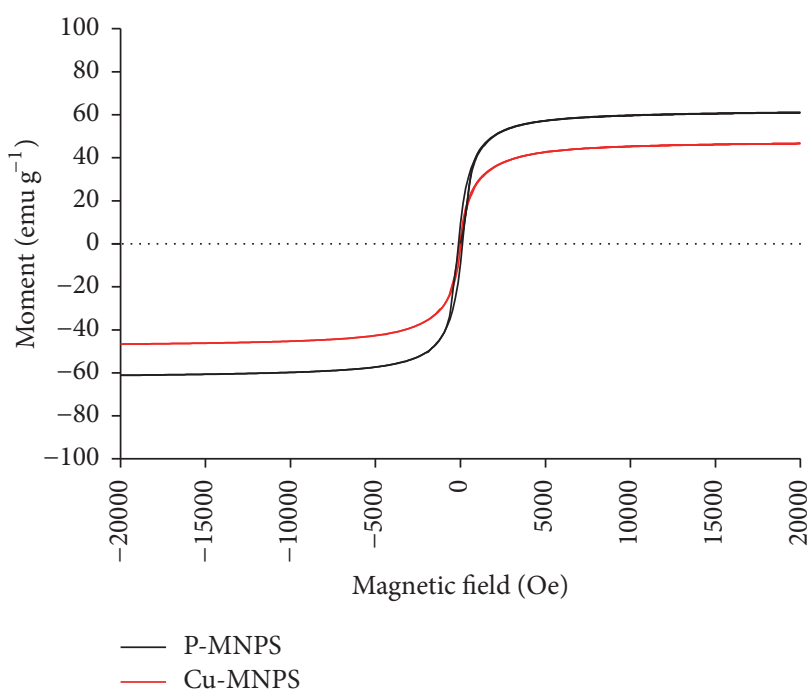

FIGURE 6: Vibrating sample magnetometry curves of u P-MNPs and Cu-MNPs.

TABLE 1: Elemental analysis of Cu-MNPs by energy-dispersive X-ray spectroscopy.

\begin{tabular}{lc}
\hline Element & Mass percentage (\%) \\
\hline $\mathrm{C}$ & 21.49 \\
$\mathrm{~N}$ & 0.51 \\
$\mathrm{O}$ & 19.74 \\
$\mathrm{Fe}$ & 10.89 \\
$\mathrm{Co}$ & 2.61 \\
$\mathrm{Cu}$ & 44.75 \\
\hline Total & 100 \\
\hline
\end{tabular}

$781.09 \mathrm{eV})$, and $\mathrm{Cu}(2 \mathrm{p}, 931.78 \mathrm{eV})$ are obviously observed. XPS shows that the oxidation state of copper was a mixture of oxidized forms including two states $\left(\mathrm{Cu}^{0}, \mathrm{Cu}^{1+}\right.$ and $\left.\mathrm{Cu}^{2+}\right)$. The strong peak at $931.78 \mathrm{can}$ be ascribed to $\mathrm{Cu}^{0}$ and/or $\mathrm{Cu}^{1+}$ while the small peak around 937.6 can be ascribed to $\mathrm{Cu}^{2+}$. It has been reported that $\mathrm{Cu}^{0}$ and $\mathrm{Cu}^{1+}$ are hard to distinguish owing to that there is about $0.3 \mathrm{eV}$ between them in binding energy [30]. The small peak at 943.6 reveals a $\mathrm{Cu}^{2+}$ oxidized form. In addition, the presence of the dominant peak at 951.7 can be assigned to $\mathrm{Cu}^{0}$ and/or $\mathrm{Cu}^{1+}$. The proportion of $\mathrm{Cu}^{0}$ and/or $\mathrm{Cu}^{1+}: \mathrm{Cu}^{2+}$ can be deduced to be about $8: 1$ by integrating the area in the XPS. Based on above results shown in XPS, it can therefore be reasonably concluded that the deposition of metallic $\mathrm{Cu}^{0}$ species on the magnetic nanoparticle surface occurred due to the reduction of $\mathrm{Cu}^{2+}$ to metallic $\mathrm{Cu}^{0}$ by $\mathrm{NaBH}_{4}$. On the other hand, the existence of $\mathrm{Cu}^{1+}$ and $\mathrm{Cu}^{2+}$ species on the magnetic nanoparticle surface was due to the fact that many metallic $\mathrm{Cu}^{0}$ species subsequently were reoxidized back $\mathrm{Cu}^{1+}$ and $\mathrm{Cu}^{2+}$ species in an aqueous environment resulting in a mixture of oxidized forms. A similar phenomenon was observed by Wang and colleagues [31]. Importantly, a high density of $\mathrm{Cu}^{2+}$ on the 

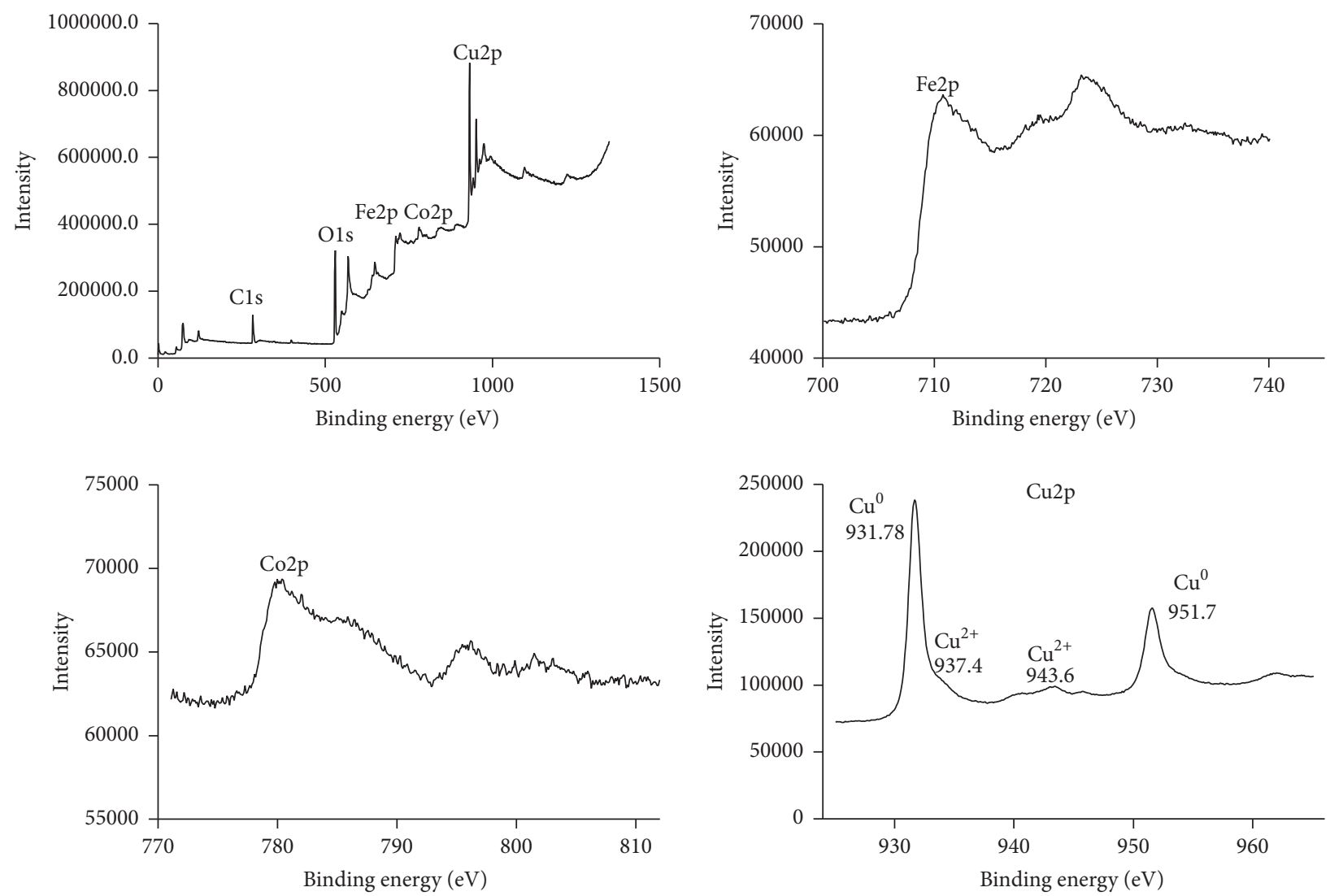

FIgURE 7: XPS spectra of the Cu-MNPs.

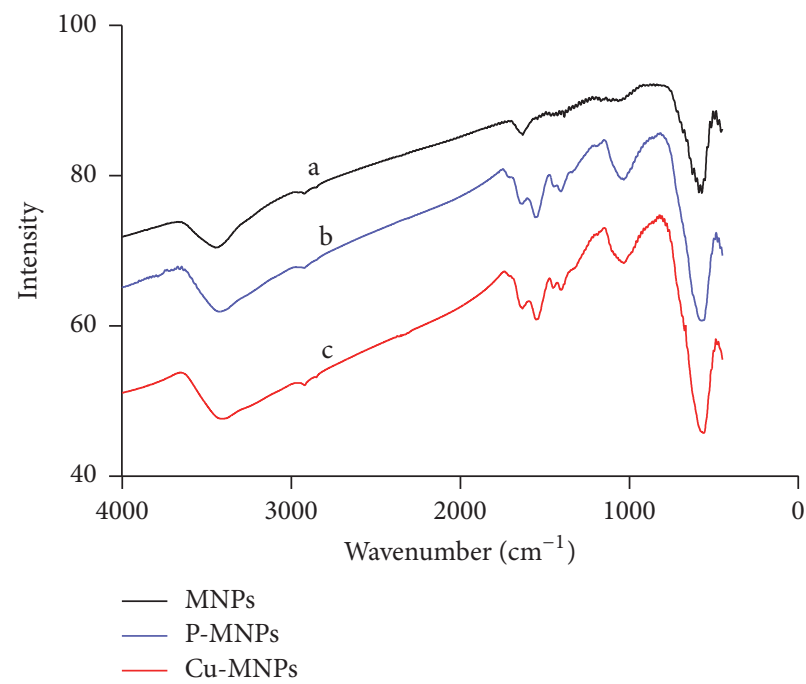

Figure 8: FT-IR spectra of MNPs, P-MNPs, and Cu-MNPs.

magnetic nanoparticle surface will contribute to protein adsorption by $\mathrm{Cu}^{2+}$-chelate affinity chromatography.

In FT-IR spectra of magnetic nanoparticles coated with or without polyacrylic acid and copper (Figure 8), the strong IR band at $580 \mathrm{~cm}^{-1}$ is attributed to $\mathrm{Fe}-\mathrm{O}$ vibrations, whereas bands at 2927, 1032, and $1647 \mathrm{~cm}^{-1}$ are associated with C$\mathrm{H}$ stretching, aliphatic $\mathrm{C}-\mathrm{N}$ stretching, and $\mathrm{C}-\mathrm{O}$ stretching vibrations due to polyacrylic acid, respectively (Figure 8, curves a, b, and c) $[24,30]$, confirming that the nanoparticles were successfully functionalized with polyacrylic acid during synthesis.

3.3. The Stability of $\mathrm{Cu}$-MNPs. The amount of $\mathrm{BHb}$ adsorbed to $\mathrm{Cu}-\mathrm{MNPs}$ as a function of time was measured to evaluate 


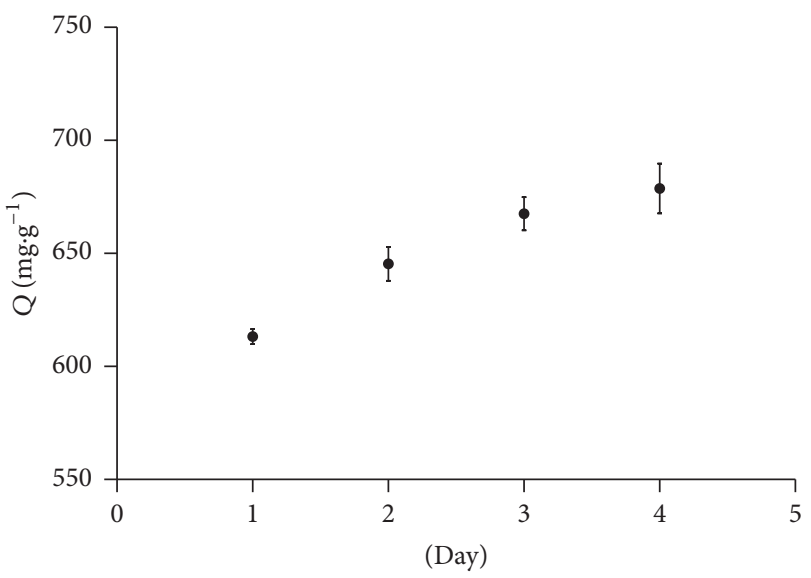

Figure 9: The amount of $\mathrm{BHb}$ adsorbed to $\mathrm{Cu}-\mathrm{MNPs}$ as a function of time.

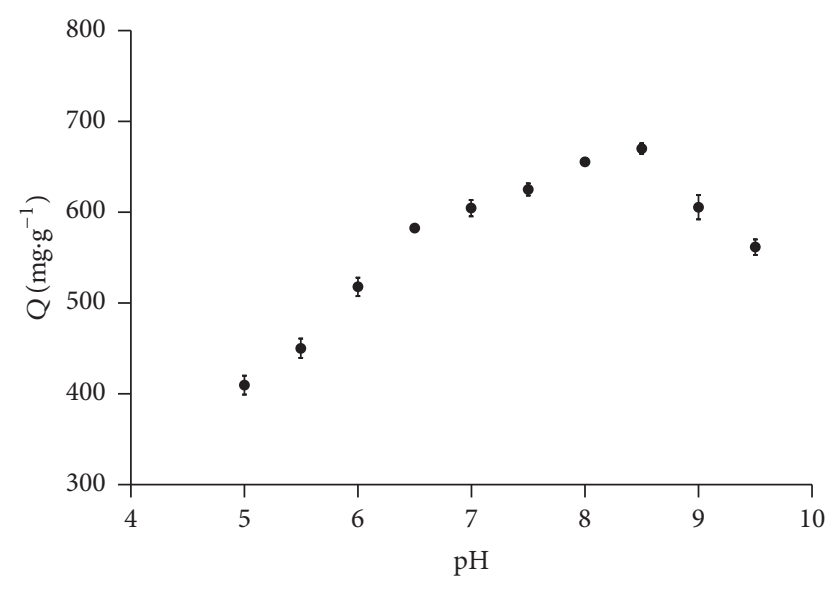

Figure 10: Effect of $\mathrm{pH}$ on adsorption of BHb to Cu-MNPs.

the stability of copper shell. As shown in Figure 9, the amount of $\mathrm{BHb}$ adsorbed to $\mathrm{Cu}-\mathrm{MNPs}$ gradually increased with day, indicating that the content of $\mathrm{Cu}^{1+}$ or $\mathrm{Cu}^{2+}$ on copper shell increased, which was attributed to the continuing oxidation of copper shell. This phenomenon would result in two different effects. On the one hand, an increased density of $\mathrm{Cu}^{1+}$ or $\mathrm{Cu}^{2+}$ may contribute to protein adsorption. On the other hand, the continuing oxidation of copper shell would reduce stability of $\mathrm{Cu}-\mathrm{MNPs}$.

3.4. Effect of $p H$. As can be seen in Figure 10, adsorption of $\mathrm{BHb}$ to $\mathrm{Cu}-\mathrm{MNPs}$ was strongly $\mathrm{pH}$-dependent, with maximum adsorption at about $\mathrm{pH}$ 8.5. Adsorption decreased below and above $\mathrm{pH}$ 8.5, in line with previous studies indicating that the optimal $\mathrm{pH}$ is between 8.0 and 9.0 [21]. With an isoelectric point near $\mathrm{pH}$ 7.0, BHb should be negatively charged above $\mathrm{pH} 7.0$ [31]. This was in favor of $\mathrm{BHb}$ adsorption by the as-synthesized nanoparticles which carried a lot of positive charges due to the existence of a large amount

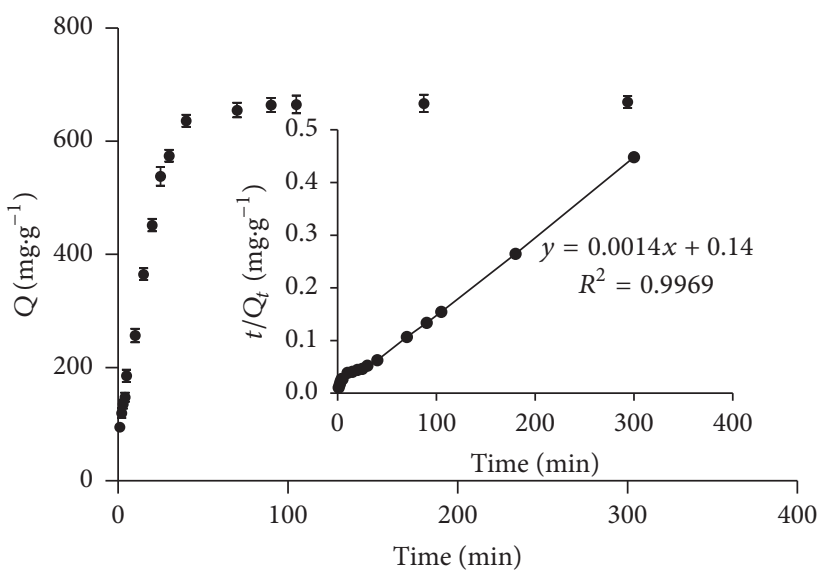

FIGURE 11: Time course of BHb adsorption to $\mathrm{Cu}-\mathrm{MNPs}$.

of $\mathrm{Cu}^{2+}$ and $\mathrm{Cu}^{1+}$ on the surface. The $\mathrm{pH}$ of the buffer has profound effect on the adsorption process owing that it can affect the charge of protein and the surface charge status of adsorbents $[32,33]$. Accordingly, buffers at $\mathrm{pH} 8.5$ were used in all subsequent experiments to preserve the electrostatic status of the target protein and the nanoparticles.

3.5. Effect of Contact Time and Adsorption Kinetics. Protein adsorption is widely interpreted in terms of well-established kinetic models [25]. As illustrated in Figure 11, adsorption of $\mathrm{BHb}$ to copper magnetic particles sharply increased from 0 to $30 \mathrm{~min}$ due to a large number of available sorption sites. However, adsorption tapered off thereafter and reached equilibrium in $90 \mathrm{~min}$. Accordingly, all subsequent adsorption experiments were allowed to proceed for $90 \mathrm{~min}$. Kinetic data were then fit to pseudo-first-order and pseudo-secondorder kinetic models. The data fit to a pseudo-first-order model reasonably well, with equation $(2) \ln \left(674.2-Q_{t}\right)=$ $6.8431-0.0917 t$ and determination coefficient $\left(R^{2}\right) 0.9727$. On the other hand, the data fit significantly better to a pseudosecond-order model with equation (3) $t / Q t=0.014 t+0.133$ and determination coefficient 0.9976 .

3.6. Effect of Initial Protein Concentration and Isothermal Adsorption. Figure 12 shows the effects of initial protein concentration on the amount of $\mathrm{BHb}$ adsorbed to $\mathrm{Cu}-$ MNPs in $90 \mathrm{~min}$. Adsorption increased with initial protein concentration up to $1.0 \mathrm{mg} \mathrm{mL}^{-1}$. Accordingly, the adsorption capacity for $\mathrm{BHb}$ was determined to be $670 \mathrm{mg} \mathrm{g}^{-1}$, which is higher than previously reported for similar devices [34, 35]. Presumably, this is due to the extremely high density of immobilized $\mathrm{Cu}^{2+}$ ions. We note that adsorption of proteins to $\mathrm{Cu}-\mathrm{MNPs}$ is attributable to metal affinity, as well as to electrostatic and hydrophobic interactions. Indeed, immobilized $\mathrm{Cu}^{2+}$ ions in nanoparticles interact strongly with protein electron donor groups such as histidine residues. In addition, proteins like $\mathrm{BHb}$ are negatively charged in basic aqueous solutions and thus can electrostatically interact with positively charged bodies like $\mathrm{Cu}-\mathrm{MNPs}$ [21]. 


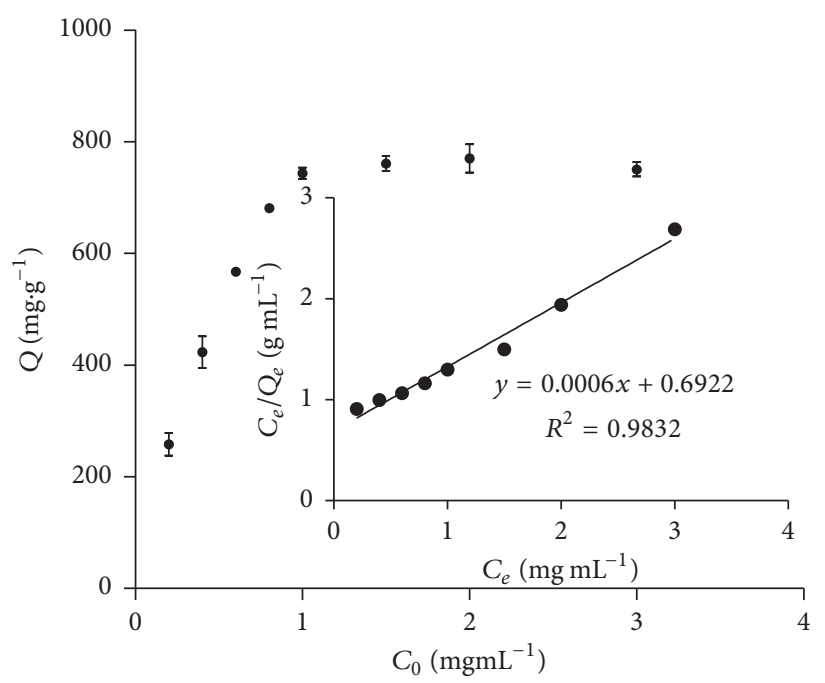

FIGURE 12: Effect of initial protein concentration on the amount of BHb adsorbed to $\mathrm{Cu}-\mathrm{MNPs}$ in 90 min.

Experimental isothermal data were fit to the Langmuir and Freundlich models as shown in Figure 12. Fitting to the Langmuir model yielded the equation (4) $C_{e} / Q_{e}=$ $0.0015 C_{e}+0.1712$, with determination coefficient 0.9986 . Based on this equation, the maximum adsorption capacity $\left(Q_{m}\right)$ was calculated to be $666 \mathrm{mgg}^{-1}$, which is very close to the experimental value of about $670 \mathrm{mg} \mathrm{g}^{-1}$. On the other hand, fitting to the Freundlich model yielded equation (5); a significantly lower determination coefficient $\left(R^{2}\right)$ of 0.8889 was obtained. Thus, isothermal data fit the Langmuir model significantly better, indicating that $\mathrm{BHb}$ interacts with $\mathrm{Cu}$ MNPs by monolayer adsorption [21].

3.7. Selectivity. Due to similarities in abundance, molecular weight, and volume [36], BSA was used as a model competitor to evaluate the selectivity of $\mathrm{Cu}-\mathrm{MNPs}$ for $\mathrm{BHb}$. BSA and hemoglobin produce characteristic peaks at $280 \mathrm{~nm}$ and $406 \mathrm{~nm}$ in the UV-visible range (Figure 13), respectively. Thus, these peaks were also used to estimate their respective concentrations. The peak at $406 \mathrm{~nm}$ sharply decreased and nearly disappeared from the supernatant after $\mathrm{BHb}$ was incubated with $\mathrm{Cu}-\mathrm{MNPs}$ by itself (Figure 13(a)), indicating efficient and selective adsorption. In contrast, the peak at $280 \mathrm{~nm}$ did not significantly decrease after adsorption of solutions containing BSA, by itself or in combination with $\mathrm{BHb}$ (Figures 13(b) and 13(c)), indicating negligible adsorption. Accordingly, the adsorption rate was calculated to be $87 \%$ for $\mathrm{BHb}$ and $25 \%$ for BSA (Figure 13(e)). In addition, solutions containing $\mathrm{BHb}$, by itself or in combination with BSA, turned from reddish brown to a light color after incubation with $\mathrm{Cu}-\mathrm{MNPs}$ (Figure 13(f)), indicating specific adsorption of hemoglobin. Taken together, these results show that $\mathrm{Cu}-$ MNPs selectively adsorb $\mathrm{BHb}$, likely because it contains 24 surface histidine residues, while BSA contains only two accessible histidines $[37,38]$. Thus, $\mathrm{BHb}$ is much easier to capture than albumin by affinity to immobilized metal ions.
3.8. Depletion of Hemoglobin from Human Blood Samples. To assess potential utility in the clinic, a fresh sample of human blood was diluted 100-fold and incubated with $\mathrm{Cu}$ MNPs. The characteristic hemoglobin peak at $406 \mathrm{~nm}$ clearly diminished after adsorption, along with the red color of the sample. Indeed, about $87 \%$ of hemoglobin was removed (Figure 13(e)). SDS-PAGE analysis (Figure 14) also indicated that the nanoparticles adsorbed hemoglobin, but not other proteins. Consequently, hemoglobin was recovered from nanoparticles after elution with 10,20, and $100 \mathrm{mM}$ imidazole (lanes 1, 3, and 4 in Figure 14). Collectively, the data indicate that $\mathrm{Cu}-\mathrm{MNPs}$ may be used to effectively remove target proteins and have potential value in clinical testing of human blood.

\section{Conclusions}

In conclusion, we present a facile route to deposit hierarchical copper shells on magnetic nanoparticles, which can then be used to capture hemoglobin. We note that after deposition, copper shells undergo partial reoxidation to $\mathrm{Cu}^{2+}$ and $\mathrm{Cu}^{1+}$, resulting in a mixture of copper oxidized forms. This mixture both protects the magnetic core and provides a high density of $\mathrm{Cu}^{2+}$ ions that strongly adsorb histidinerich proteins. Indeed, UV-visible spectrophotometry and SDS-PAGE analysis demonstrated that $\mathrm{Cu}-\mathrm{MNPs}$ specifically capture $\mathrm{BHb}$ due to strong interactions between $\mathrm{Cu}^{2+}$ and histidine residues. Kinetic adsorption data followed pseudosecond-order kinetics, while isothermal data were described well by the Langmuir model. Importantly, the nanoparticles specifically depleted hemoglobin from human blood, demonstrating that the nanocomposites have potential application in removing highly abundant histidine-rich proteins from complex samples. 


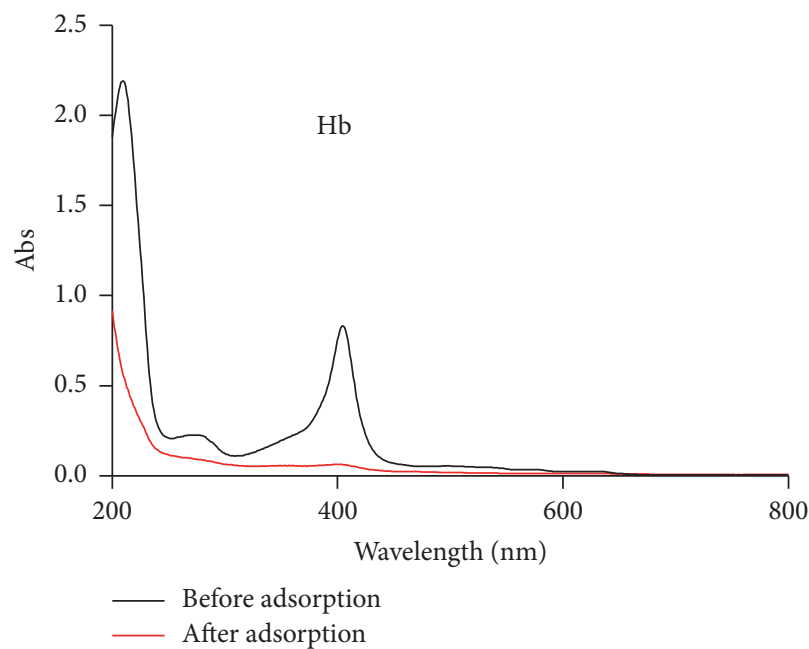

(a)

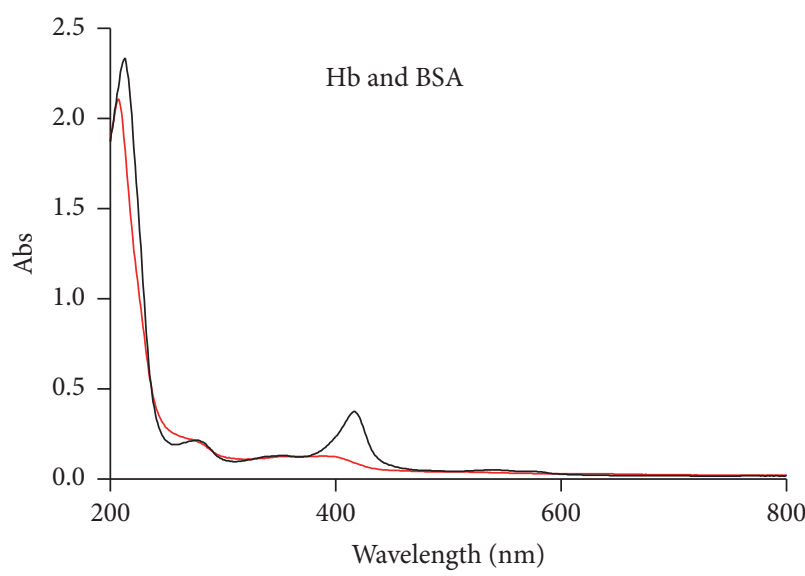

Before adsorption

After adsorption

(c)

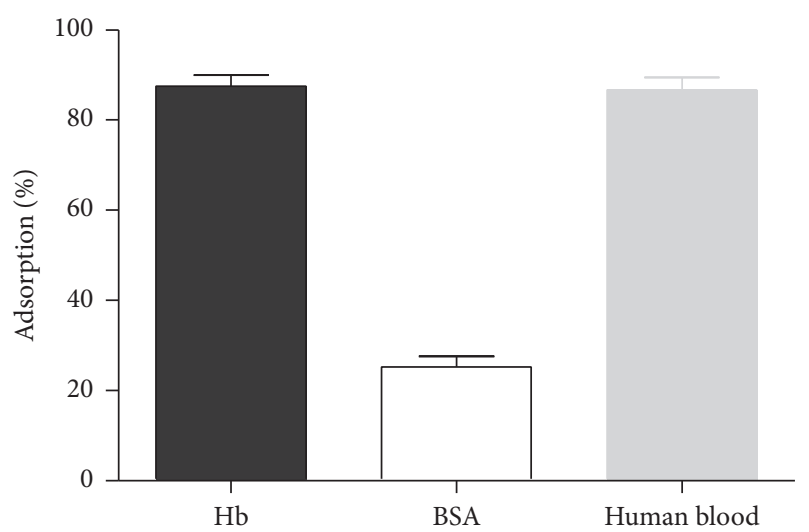

(e)

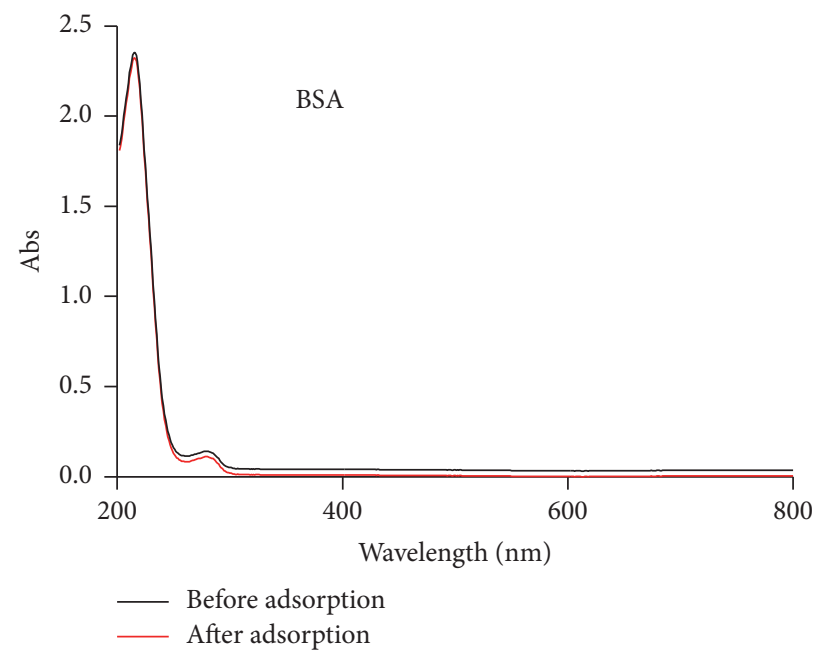

(b)

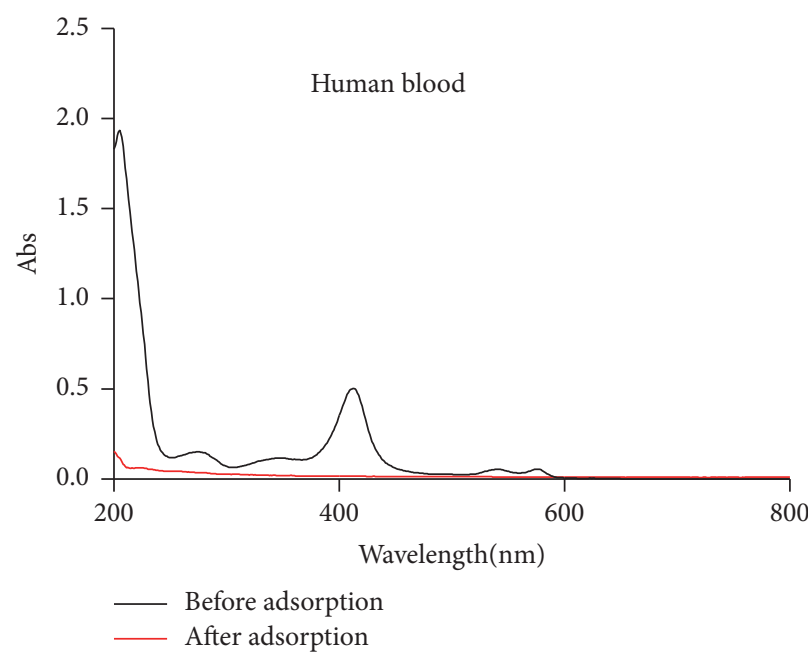

(d)

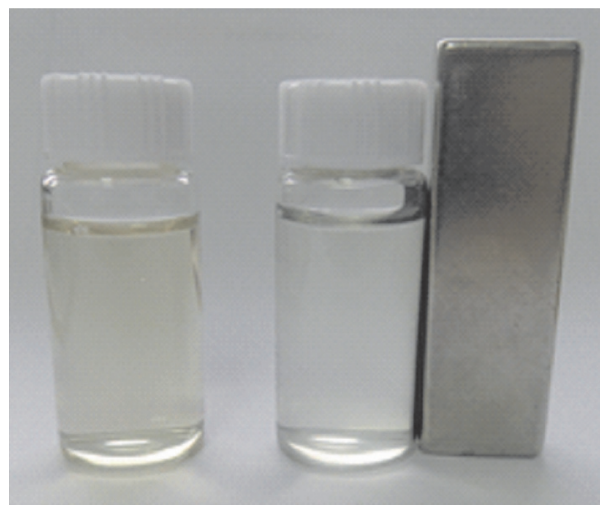

(f)

FIgURE 13: Selectivity of Cu-MNPs for BHb, as assessed visually (f) and by UV-Visible spectrophotometry. 


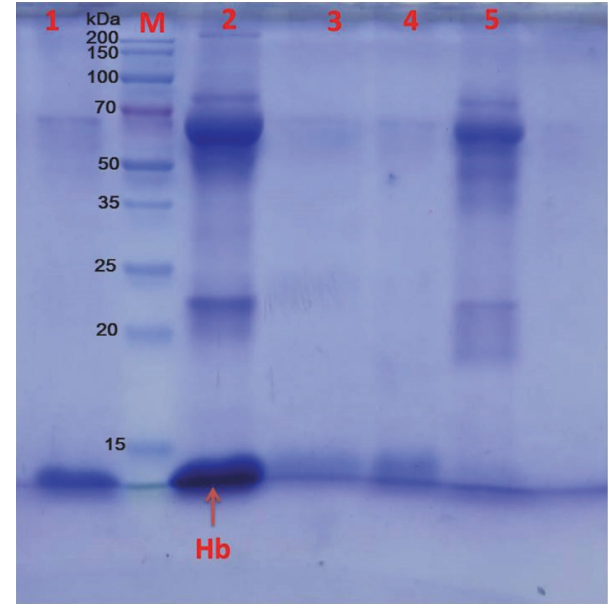

FIGURE 14: SDS-PAGE analysis of a human blood sample incubated with Cu-MNPs. Lane M, protein marker; lane 1, elution with $100 \mathrm{mM}$ imidazole; lane 2, human blood diluted 100-fold; lane 3, elution with $10 \mathrm{mM}$ imidazole; lane 4, elution with $20 \mathrm{mM}$ imidazole; lane 5, supernatant after adsorption.

\section{Competing Interests}

The authors declare that they have no competing financial interests.

\section{Acknowledgments}

This work was generously supported by the Graduate Innovation Program (no. YJSCX201518Y) of Xinxiang Medical University, by the Youth Backbone Teacher Training Program (no. 2016GGJS-104) and the Nature Science Plan Program (no. 12B180030) of the Education Department of Henan Province, and by the National Natural Science Foundation of China (no. U1304302).

\section{References}

[1] A. Romero and C. Schal, "Blood constituents as phagostimulants for the bed bug Cimex lectularius L.", Journal of Experimental Biology, vol. 217, no. 4, pp. 552-557, 2014.

[2] M. Iranifam, "Analytical applications of chemiluminescencedetection systems assisted by magnetic microparticles and nanoparticles," Trends in Analytical Chemistry, vol. 51, pp. 5170, 2013.

[3] A. Vallée-Bélisle, F. Ricci, T. Uzawa, F. Xia, and K. W. Plaxco, "Bioelectrochemical switches for the quantitative detection of antibodies directly in whole blood," Journal of the American Chemical Society, vol. 134, no. 37, pp. 15197-15200, 2012.

[4] N. Zolotarjova, P. Mrozinski, H. Chen, and J. Martosella, "Combination of affinity depletion of abundant proteins and reversed-phase fractionation in proteomic analysis of human plasma/serum," Journal of Chromatography A, vol. 1189, no. 1-2, pp. 332-338, 2008.

[5] X. Zhu, M. Lv, H. Wang, and W. Guan, "Identification of circulating microRNAs as novel potential biomarkers for gastric cancer detection: a systematic review and meta-analysis," Digestive Diseases and Sciences, vol. 59, no. 5, pp. 911-919, 2014.
[6] E. K. M. Ueda, P. W. Gout, and L. Morganti, "Current and prospective applications of metal ion-protein binding," Journal of Chromatography A, vol. 988, no. 1, pp. 1-23, 2003.

[7] L. Rong, G. Chen, and W. Zhao, "Immobilized metal ion affinity chromatography methods, principles, characteristics and applications for protein separation," Chemistry Bulletin, vol. 68, no. 5, pp. 352-360, 2005.

[8] X. Chen, S. Chen, J. Liu, and J. Wang, "Isolation of hemoglobin from human blood using solid phase extraction with lanthanum(III) modified zeolite," Microchimica Acta, vol. 165, no. 1-2, pp. 217-222, 2009.

[9] S. Wang, N. Xiong, X.-Y. Dong, and Y. Sun, "A novel nickelchelated surfactant for affinity-based aqueous two-phase micellar extraction of histidine-rich protein," Journal of Chromatography A, vol. 1320, pp. 118-124, 2013.

[10] S.-H. Huang and R.-S. Juang, "Biochemical and biomedical applications of multifunctional magnetic nanoparticles: a review," Journal of Nanoparticle Research, vol. 13, no. 10, pp. 4411-4430, 2011.

[11] A.-H. Lu, E. L. Salabas, and F. Schüth, "Magnetic nanoparticles: synthesis, protection, functionalization, and application," Angewandte Chemie-International Edition, vol. 46, no. 8, pp. 1222 1244, 2007.

[12] R. A. Frimpong and J. Z. Hilt, "Magnetic nanoparticles in biomedicine: synthesis, functionalization and applications," Nanomedicine, vol. 5, no. 9, pp. 1401-1414, 2010.

[13] H. Rui, R. Xing, Z. Xu, Y. Hou, S. Goo, and S. Sun, "Synthesis, functionalization, and biomedical applications of multifunctional magnetic nanoparticles," Advanced Materials, vol. 22, no. 25, pp. 2729-2742, 2010.

[14] M. Zhang, X. He, L. Chen, and Y. Zhang, "Preparation and characterization of iminodiacetic acid-functionalized magnetic nanoparticles and its selective removal of bovine hemoglobin," Nanotechnology, vol. 22, no. 6, Article ID 065705, 2011.

[15] X. Guo, F. Mao, W. Wang, Y. Yang, and Z. Bai, "Sulfhydrylmodified $\mathrm{Fe}_{3} \mathrm{O}_{4} @ \mathrm{SiO}_{2}$ core/shell nanocomposite: synthesis and toxicity assessment in vitro," ACS Applied Materials and Interfaces, vol. 7, no. 27, pp. 14983-14991, 2015.

[16] J. Wang, S. Zheng, Y. Shao, J. Liu, Z. Xu, and D. Zhu, "Aminofunctionalized $\mathrm{Fe}_{3} \mathrm{O}_{4} @ \mathrm{SiO}_{2}$ core-shell magnetic nanomaterial as a novel adsorbent for aqueous heavy metals removal," Journal of Colloid and Interface Science, vol. 349, no. 1, pp. 293-299, 2010.

[17] S. Ayyappan, J. Philip, and B. Raj, "Effect of digestion time on size and magnetic properties of spinel $\mathrm{CoFe}_{2} \mathrm{O}_{4}$ nanoparticles," Journal of Physical Chemistry C, vol. 113, no. 2, pp. 590-596, 2009.

[18] S. Ayyappan, S. Mahadevan, P. Chandramohan, M. P. Srinivasan, J. Philip, and B. Raj, "Influence of $\mathrm{Co}^{2+}$ Ion concentration on the size, magnetic properties, and purity of $\mathrm{CoFe}_{2} \mathrm{O}_{4}$ Spinel ferrite nanoparticles," Journal of Physical Chemistry C, vol. 114, no. 14, pp. 6334-6341, 2010.

[19] G. Jian, Y. Liu, X. He, L. Chen, and Y. Zhang, "Click chemistry: a new facile and efficient strategy for the preparation of $\mathrm{Fe}_{3} \mathrm{O}_{4}$ nanoparticles covalently functionalized with IDA-Cu and their application in the depletion of abundant protein in blood samples," Nanoscale, vol. 4, no. 20, pp. 6336-6342, 2012.

[20] M. Zhang, X. He, L. Chen, and Y. Zhang, "Preparation of IDA-Cu functionalized core-satellite $\mathrm{Fe}_{3} \mathrm{O}_{4}$ /polydopamine/Au magnetic nanocomposites and their application for depletion of abundant protein in bovine blood," Journal of Materials Chemistry, vol. 20, no. 47, pp. 10696-10704, 2010. 
[21] C. Ding, X. Ma, X. Yao, and L. Jia, "Facile synthesis of copper(II)-decorated magnetic particles for selective removal of hemoglobin from blood samples," Journal of Chromatography A, vol. 1424, pp. 18-26, 2015.

[22] J.-W. Liu, T. Yang, L.-Y. Ma, X.-W. Chen, and J.-H. Wang, "Nickel nanoparticle decorated graphene for highly selective isolation of polyhistidine-tagged proteins," Nanotechnology, vol. 24, no. 50, Article ID 505704, 2013

[23] I. S. Lee, N. Lee, J. Park et al., "Ni/NiO core/shell nanoparticles for selective binding and magnetic separation of histidinetagged proteins," Journal of the American Chemical Society, vol. 128, no. 33, pp. 10658-10659, 2006.

[24] X. Liu, Q. Hu, Z. Fang, Q. Wu, and Q. Xie, "Carboxyl enriched monodisperse porous $\mathrm{Fe}_{3} \mathrm{O}_{4}$ nanoparticles with extraordinary sustained-release property," Langmuir, vol. 25, no. 13, pp. 72447248, 2009.

[25] Y. Liu, M. Chen, and H. Yongmei, "Study on the adsorption of $\mathrm{Cu}(\mathrm{II})$ by EDTA functionalized $\mathrm{Fe}_{3} \mathrm{O}_{4}$ magnetic nanoparticles," Chemical Engineering Journal, vol. 218, pp. 46-54, 2013.

[26] Y. S. Ho and G. Mckay, "Pseudo-second order model for sorption processes," Process Biochemistry, vol. 34, no. 5, pp. 451-465, 1999.

[27] B. H. Hameed and F. B. M. Daud, "Adsorption studies of basic dye on activated carbon derived from agricultural waste: hevea brasiliensis seed coat," Chemical Engineering Journal, vol. 139, no. 1, pp. 48-55, 2008.

[28] I. Langmuir, "The constitution and fundamental properties of solids and liquids. Part II. Liquids," Journal of the American Chemical Society, vol. 38, no. 5, pp. 102-105, 1917.

[29] Q. Gai, F. Qu, and Y. Zhang, "The preparation of BHb-molecularly imprinted gel polymers and its selectivity comparison to BHb and BSA," Separation Science and Technology, vol. 45, no. 16, pp. 2394-2399, 2010.

[30] P. Mondal, A. Sinha, N. Salam, A. S. Roy, N. R. Jana, and S. M. Islam, "Enhanced catalytic performance by copper nanoparticle-graphene based composite," RSC Advances, vol. 3, no. 16, pp. 5615-5623, 2013.

[31] H. Shirahama, K. Suzuki, and T. Suzawa, "Bovine hemoglobin adsorption onto polymer latices," Journal of Colloid and Interface Science, vol. 129, no. 2, pp. 483-490, 1989.

[32] Y. T. Zhou, C. Branfordwhite, H. L. Nie, and L. M. Zhu, "Adsorption mechanism of $\mathrm{Cu}^{2+}$ from aqueous solution by chitosan-coated magnetic nanoparticles modified with alphaketoglutaric acid," Journal of Colloid and Interface Science, vol. 330, no. 1, pp. 29-37, 2009.

[33] G. Sheng, J. Li, D. Shao et al., "Adsorption of copper(II) on multiwalled carbon nanotubes in the absence and presence of humic or fulvic acids," Journal of Hazardous Materials, vol. 178, no. 1-3, pp. 333-340, 2010.

[34] Z.-Y. Ma, Y.-P. Guan, X.-Q. Liu, and H.-Z. Liu, "Preparation and characterization of micron-sized non-porous magnetic polymer microspheres with immobilized metal affinity ligands by modified suspension polymerization," Journal of Applied Polymer Science, vol. 96, no. 6, pp. 2174-2180, 2005.

[35] M. Zhang, D. Cheng, X. He, L. Chen, and Y. Zhang, "Magnetic silica-coated sub-microspheres with immobilized metal ions for the selective removal of bovine hemoglobin from bovine blood," Chemistry - An Asian Journal, vol. 5, no. 6, pp. 1332-1340, 2010.

[36] Z. Lin, F. Yang, X. He, and Y. Zhang, "Organic-inorganic hybrid silica as supporting matrices for selective recognition of bovine hemoglobin via covalent immobilization," Journal of Separation Science, vol. 32, no. 22, pp. 3980-3987, 2009.

[37] G. E. Wuenschell, E. Naranjo, and F. H. Arnold, "Aqueous twophase metal affinity extraction of heme proteins," Bioprocess Engineering, vol. 5, no. 5, pp. 199-202, 1990.

[38] E. S. Hemdan, Y. Zhao, E. Sulkowski, and J. Porath, "Surface topography of histidine residues: a facile probe by immobilized metal ion affinity chromatography," Proceedings of the National Academy of Sciences of the United States of America, vol. 86, no. 6, pp. 1811-1815, 1989. 

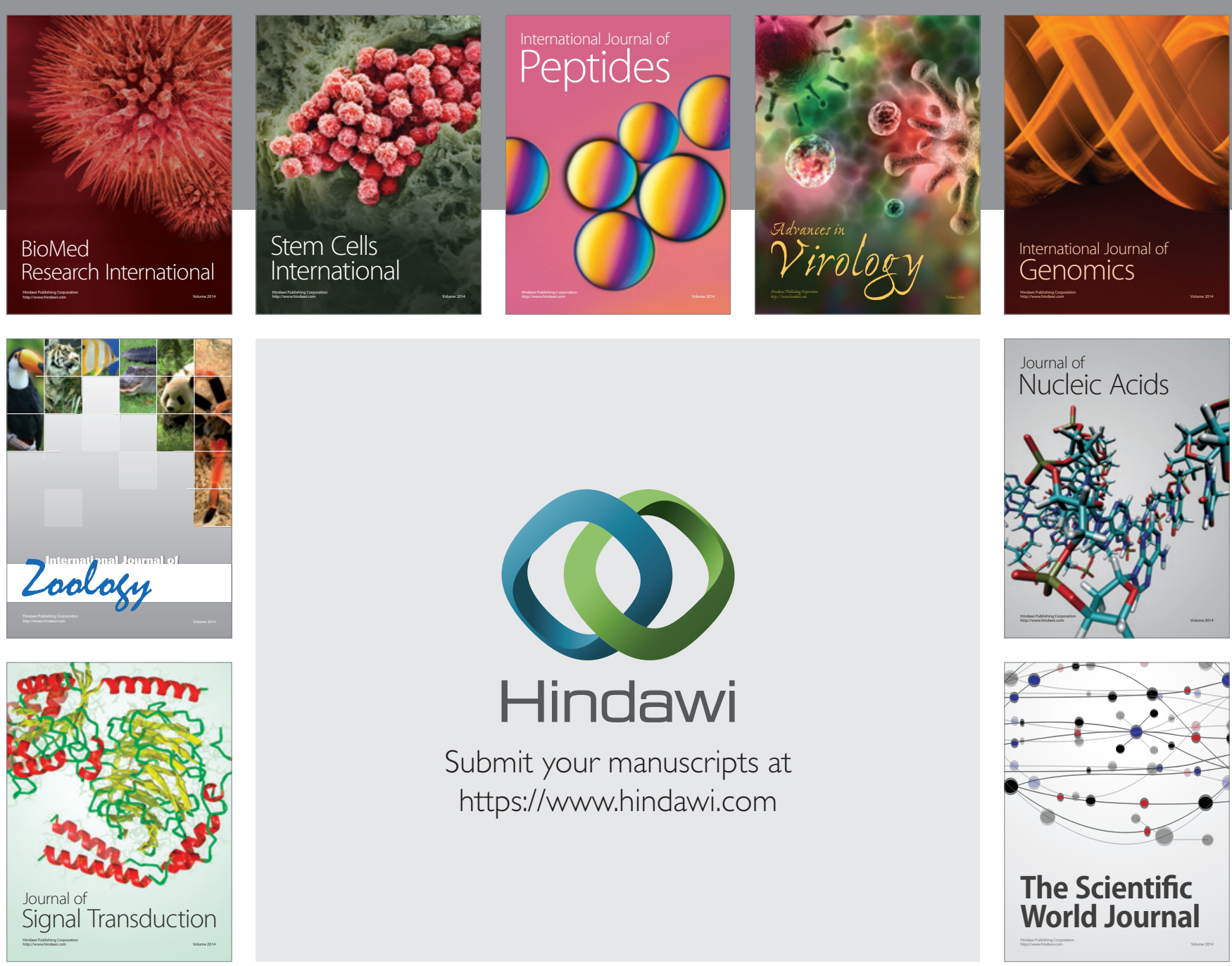

Submit your manuscripts at

https://www.hindawi.com
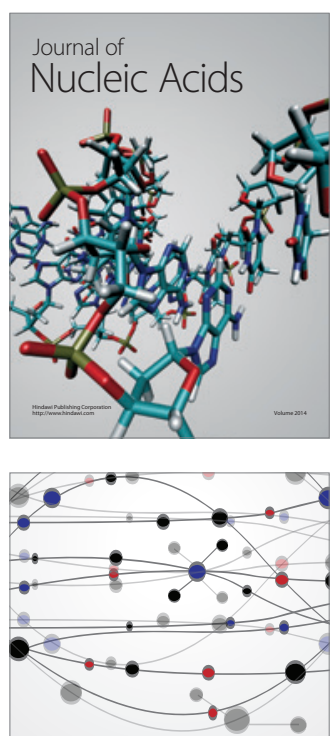

The Scientific World Journal
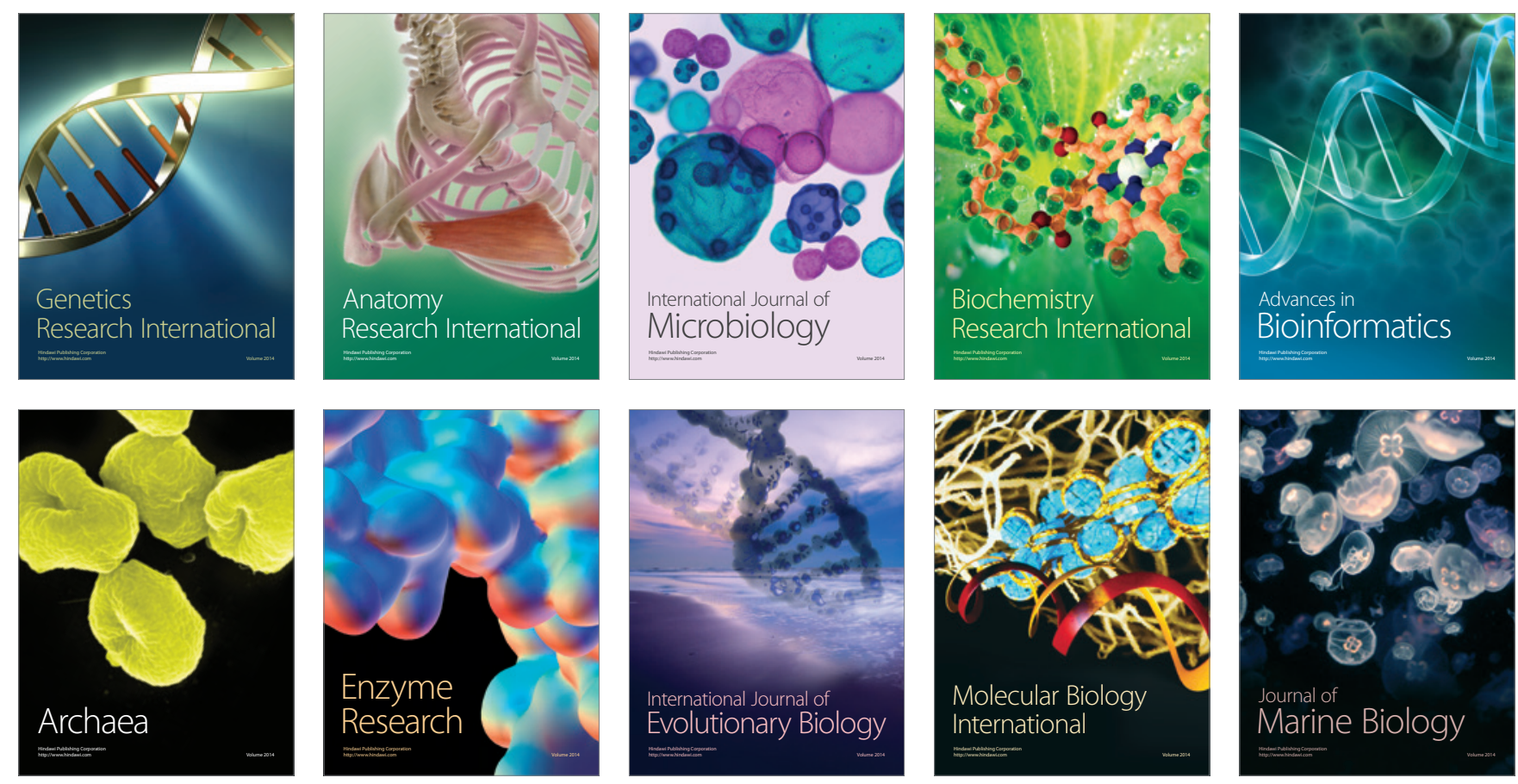